\title{
長期透析患者の骨変化
}

$\begin{array}{rlllll}\text { 国立長崎中央病院 } & \text { 整形外科 } & & & \\ \text { 松 } & \text { 本 } & \text { 智 子・秋 山 } & \text { 寛 } & \text { 治 } \\ \text { 泉 } & & \text { 賢太郎・大 } & \text { 坪 } & \text { 義 } & \text { 昌 } \\ \text { 藤 } & \text { 田 } & \text { 雅 章 } & & & \end{array}$

黒木医院

黒木 隆 亨

\section{Bone Changes During Hemodialysis for a Long Time}

by

Tomoko Matsumoto, Kanji Akiyama, Yoshimasa Ootubo, Kentaro Izumi, Masaaki Fujita, " Isao Arai and ${ }^{* *}$ Takanori Kuroki

Department of Orthopaedic Surgery and *Internal medicine National Nagasaki Chuo Hospital **Kuroki hospital

\begin{abstract}
During hemodialysis, bone is affected by several factors. In order to study the effects of water for dialysate preparation on bone, we compared bone changes in the patients who were hemodialysed for over ten years in two different hospitals. Softed water was used for a dialysate preparation in one hospital A, and reverse osmosis was used in another hospital B. All 3 patients in A have severe bone pain and remarkable radiographic changes in bone such as fractures and bone absorption. All 11 patients except one in $B$ have no symptom. The mineral content of bone is dcreased in all 15 patients. These results show the fact that water for dialysate preparaion is one of the important factor in renal osteodystrophy.
\end{abstract}

\section{はじめに}

長期間の透析により骨は種々の因子から影響をうけ 変化をきたすことが考えられる.今回, 透析水の影響 を知るために，透析法の異なる 2 つの施設間で 10 年 以上の長期にわたって透析を受けている患者の骨変化 を比較した。

\section{対象及び方法}

対象はA，B 2 つの施設で週 3 回，10 年以上透析 を受けている患者 15 人で，両者間の症例数の差が大 きいことは問題だが，平均年齢，透析期間はほほ類似 していた (表 1 ). 2 施設間の透析方法は水処理の方 法がもっとも異なり， A では軟化のみおこない， Bで
は逆浸透処理をしている。

調査方法は全員を直接診察し, 臨床症状および全身 骨のX線像を調べた。また第 3 腰椎の骨塩量を QCT 法で，第 2 中手骨の骨塩量を MD 法で測定した. 臨 床症状の強い症例については電解質の他に上皮小体ホ ルモンや血中のアルミニウム量についても測定した.

\section{結果}

臨床的に強い骨関節痛を訴えたのは 15 人中 3 人で いずれも 1 つの施設(A)に集中していた. 他の施設(B)で 透析を受けている患者は 1 人が軽度の肩関節痛を訴え たが他はほとんど症状の訴えはなかった。ただその内 の 1 人は透析 9 年目に上皮小体の摘出術をうけその後 に痛みが消失している，全身骨のX線所見では 2 施設 
表 12 施設の対象患者と透析水の処理法

\begin{tabular}{|c|c|c|}
\hline & $\mathrm{A}$ 施設 & B 施設 \\
\hline 患者数 & 3 人（女性 3 ) & $\begin{array}{c}12 \text { 人（男性 } 6 \text {, 女性 } \\
6 \text { ) }\end{array}$ \\
\hline 年＼cjkstart齢 & $\begin{array}{c}\text { 35才から55才 } \\
\text { (平均43才) }\end{array}$ & $\begin{array}{l}\text { 28才から63才 } \\
\text { (平均 } 44 \text { 才) }\end{array}$ \\
\hline 透析期間 & $\begin{array}{c}11 \text { 年から } 15 \text { 年 } 1 \text { 力月 } \\
\text { (平均 } 12 \text { 年 } 6 \text { 力月) }\end{array}$ & $\begin{array}{c}10 \text { 年から } 16 \text { 年 } 5 \text { 力月 } \\
\text { (平均 } 12 \text { 年 } 3 \text { 力月) }\end{array}$ \\
\hline 水処理法 & 軟化装置 & 逆浸透装置 \\
\hline
\end{tabular}

表 2 各施設の患者の骨関節痛およびX 線像の比較

\begin{tabular}{cccc}
\hline \hline & & $\mathrm{A}(3$ 人) & $\mathrm{B}(12$ 人) \\
\hline 骨関節痛 & 激しい痛み & 3 & 0 \\
& 軽度の痛み & 0 & 1 \\
& ほとんどなし & 0 & 11 \\
\hline $\mathrm{X}$ 線変化 & 骨 折 & 3 & 0 \\
& 骨吸収像 & 2 & 2 \\
& 骨梁の粗造化 & 1 & 6 \\
& 骨濃度の低下 & 3 & 4 \\
\hline
\end{tabular}

表 3 MD 法で測定した中手骨の骨塩量， $\Sigma$ GS/D值

\begin{tabular}{ccc}
\hline \hline & $\begin{array}{c}\text { 健常者平均 }-1 \text { SD 以 } \\
\text { 内 }\end{array}$ & -1 SD下 \\
\hline $\mathrm{A}(3$ 人) & 1 人 & 2 人 \\
\hline $\mathrm{B}(12$ 人) & 4 人 & 8 人 \\
\hline
\end{tabular}

表 4 水処理の方法
1. 万過
2. 軟化
3. 脱イオン
4.活性炭による吸着
5 . 蒸留
6 . 逆浸透

の患者とも骨濃度の低下や骨梁の粗造化がみられた が，特に臨床的に骨関節痛の強いA施設の患者は骨膜 下骨吸収像や胁骨，鎖骨などの骨折を合併していた。 またそのうちの 1 例では両側の大腿骨頭壊死症を認め た (表 2 ).

骨塩量の測定では MD 法で，中手骨の $\Sigma$ GS/D につ いて検討すると, 全例同年令の健常人の平均值以下を

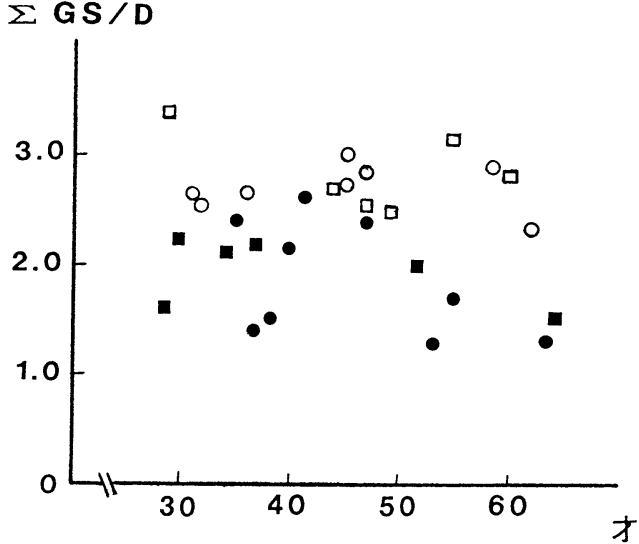

年㱓

図 1 透析歴 2 年以内と透析歴 10 年以上の骨塩量の比較 透析歴 $0 \sim 2$ 年以内 $\square$ 男性 ○女性 透析歴10年以上 口男性 ○性

透析歴10年以上の症例は男女とも中手骨の骨塩量が低下 している.

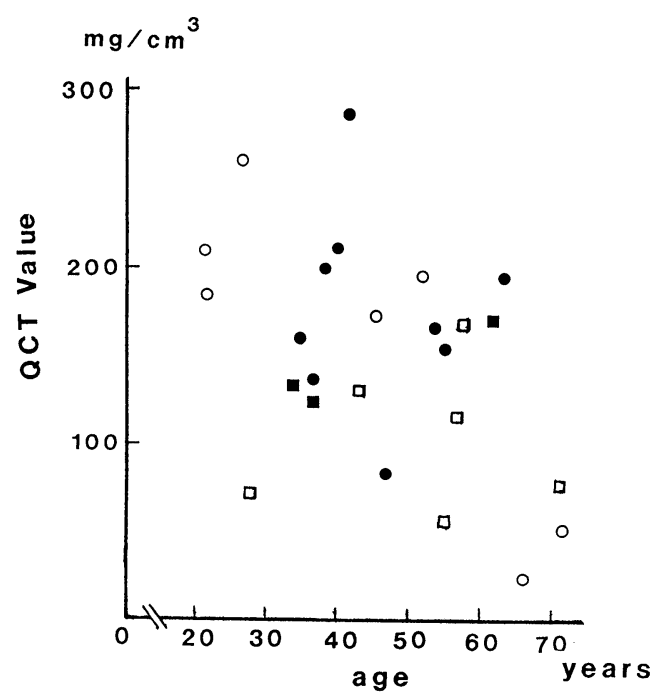

図 2 QCT 法で測定した第 3 腰椎の骨塩量 健常人口男性 ○女性 10 年以上透析例口男性

$\mathrm{QCT}$ 值は 10 年以上の透析例と健常人との有意差は認め られない。

示し, 低下の程度に両施設で違いは認めなかった（表 3 ). また, 腎不全の患者で透折歴 2 年以内の患者と 比較した場合も, 透析歴 10 年以上の群が $\Sigma$ GS/D は 低下しており，長期透析により骨塩量が低下すること を示している (図 1). しかし, 第 3 腰椎の海綿骨の 


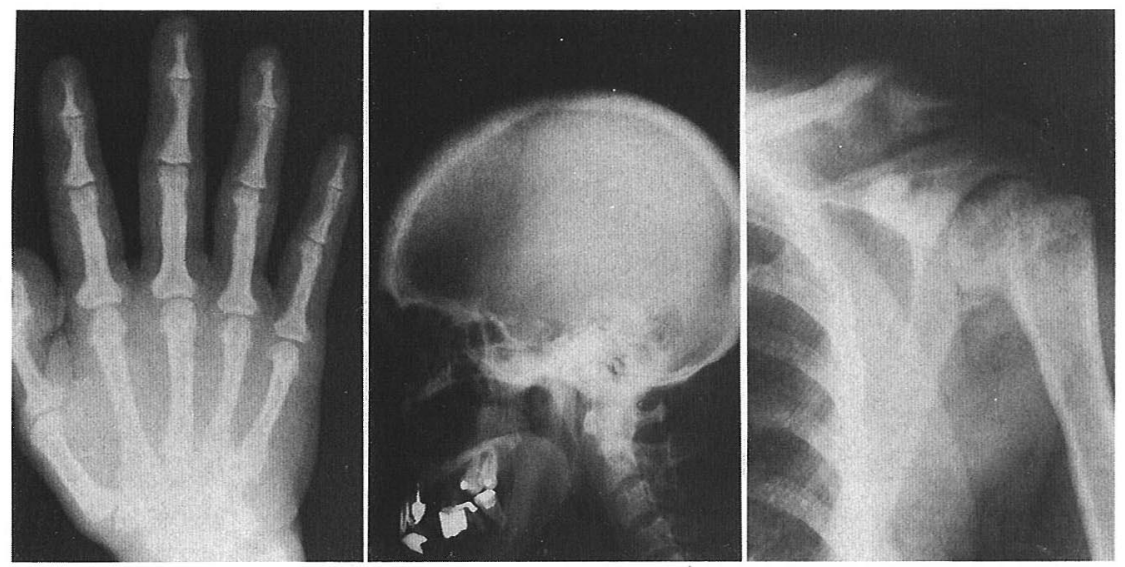

図 355 才女性 透析歴 11 年 5 力月

手指骨に骨膜下骨吸収像，頭蓋骨に salt and pepper appearance, および鎖骨骨折を認める.
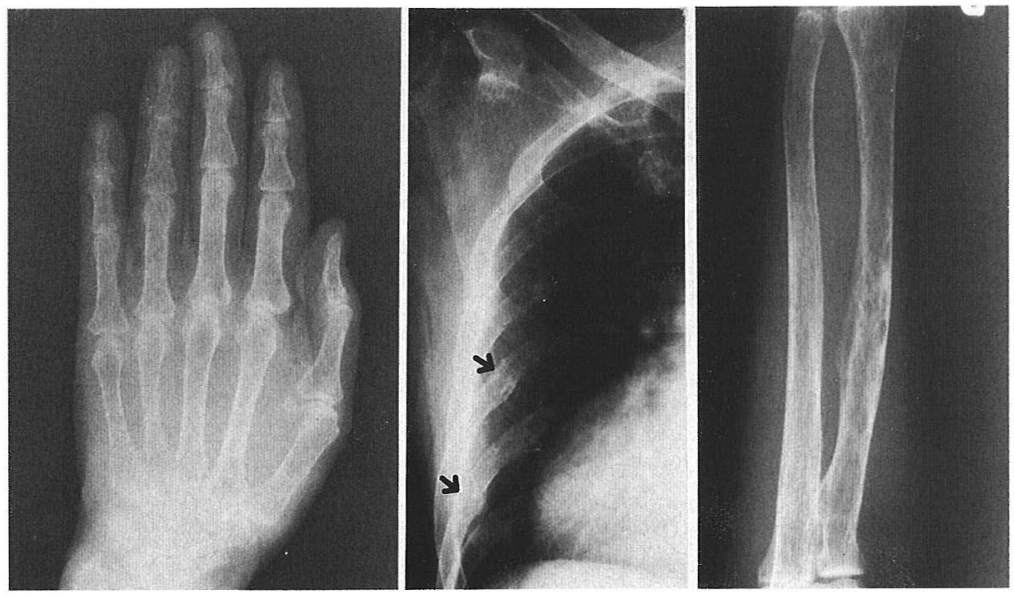

図 439 才女性 透析歴 15 年 1 力月

骨皮質は薄く, 肋骨には多発骨折を，長管骨には囊胞状の骨吸収像を認める.

骨密度をあらわす QCT 法は症例により様々な值を示

し, 健康なコントロール群と比較しても有意な差は認 めなかった（図 2).

次に臨床的に強い骨関節の痛みを訴えた 3 例につい て症例を供覧する.

症例 1.55 才女性. 透析歴 11 年 5 力月. X線像で は手指骨に骨膜下骨吸収像を, 頭蓋骨には salt and pepper appearance をままた両側の鎖骨には骨折を認 めた（図 3)。本症例は上皮小体ホルモンも 23.2 $\mathrm{ng} / \mathrm{ml}$ と上昇しており二次性上皮小体機能立進症の合 併も疑われた。

症例 2.39 才女性. 透析歴 15 年 1 力月. 肋骨に数力
所の骨折を認め，また骨皮質は薄く，長管骨には囊胞 状の骨吸収像がみられる（図4）。

症例 3.35 才女性. 透析歴 11 年. 全身, 特に両股 関節に強い痛みを訴え, 股関節の X 線像, および MRI 像上, 両側の大腿骨頭壞死症が発生している（図 5)。また本例で測定した血清のアルミニウム濃度は $139 \mu \mathrm{g} / 1$ と著しく上昇し, DFO 負荷テストでは 277

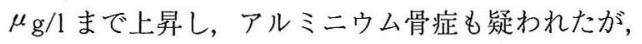
アルミニウム染色による確定診断は㧍こなっていな い.

このように臨床的に痛みの強い症例は単に骨塩量の 低下だけでなくX線学的や, 血液生化学的になんらか 

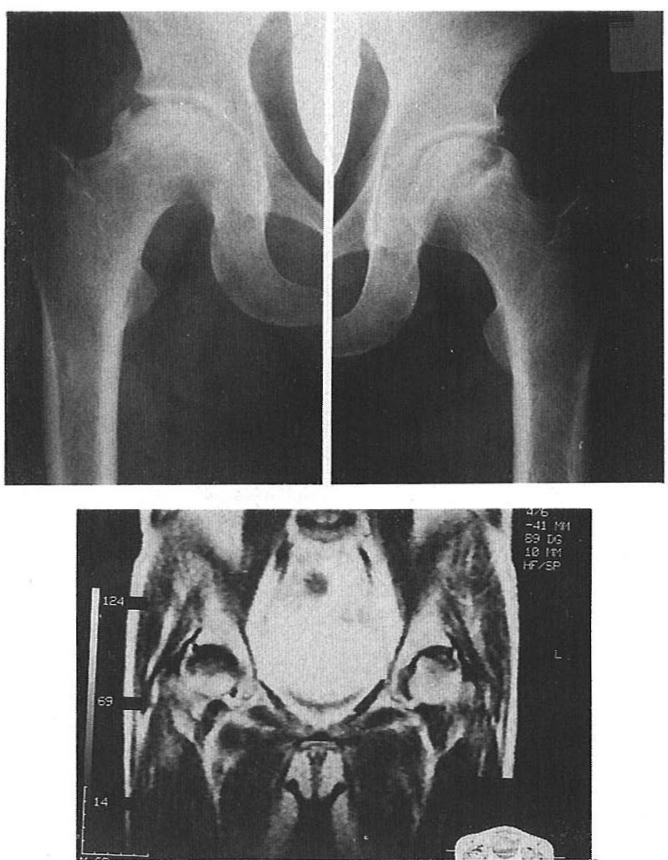

図 5 35才女性 透析歴11年 两側に大腿骨頭壊死像を認める。

の変化を認めることが多かった.

\section{考察}

腎性骨異栄養症 (ROD) は, カルシウムやリンの代 謝異常にともない骨塩量に変化をきたすことが知られ ているが, その病態は複雑で, 骨粗しょう症, 線維性 骨炎，骨軟化症，骨硬化症など多彩な骨所見を呈する. そのため, 骨塩量も測定の部位や方法により異なるこ とが想像される、今回, 第 3 腰椎の海綿骨の骨塩量を あらわす QCT 法で健常者との差ができなかったのは ROD の複雑な病態をあらわしているものと思われる. 伊東 ${ }^{1)}$ 二重エネルギー QCT 法で腰椎の骨塩量を測 定し，透析期間とは相関せず，骨病変の重症度の診断 にそのまま用いることはできなかったと述べている. 一方, MD 法で測定した中手骨の骨塩量は透析期間が 長くなるにつれて低下していることがわかった，楊 ${ }^{4}$ らは透析 13 年間で $\Sigma$ GS/D が男性 $15.4 \%$, 女性 21.2 \%低下し，特に透析 4 年目より有意に増悪したと報告 している，透析により骨塩量が低下することは諸家の ほぼ一致した意見でもある。

今回の調査で両施設の患者とも同様に骨塩量は低下
していたにかかわらず，臨床症状が大きく異なってい たのはなぜだろうか. すなわち, A 施設の患者は全員, 強い骨関節痛を訴え, 全身骨のX線変化も著明であっ たが，B施設の患者はあまり痛みを訴えずX線変化も 少なかった：それらの原因の 1 つとして透析法の違い が考えられる．2 施設の透析法では水処理の方法が最 も異なっていた. 現在水処理の方法として表 4 に示す ような方法があげられる，A施設は軟水化装置だけを 用い， B 施設は逆浸透装置を用いていた. 鈴木 ${ }^{3)}$ 軟水化装置だけではアルミニウムは半分ぐらいしか除 去されず，さらに逆浸透装置で精製することによりほ ぼ満足する值まで除去されると報告している.このこ とはアルミニウムだけでなく他の微量成分についても 同様なことが考えられる. 丸茂 ${ }^{2)} ら も$ 微量元素の過 剩あるいは減少による障害の可能性を述べている，今 回の調査で, 臨床症状や骨変化の強い3 例の血清中の アルミニウム量は $139 \mu \mathrm{g} / \mathrm{ml}, 42 \mu \mathrm{g} / \mathrm{ml}, 34 \mu \mathrm{g} / \mathrm{ml}$ (正 常值 $<10 \mu \mathrm{g} / \mathrm{ml}$ ) であり必ずしもすべてをアルミニウ ムに帰することはできない.しかし 10 年以上の長期 にわたる透析により,透析水の中の未知の微量物質が, 骨代謝になんらかの影響を及ぼしていることも考えら れる.

最近は，ROD に対する関心が高まるとともに水処 理の方法も改善され, 逆浸透装置を使用している施設 も増えてきている. また，活性化ビタミン Dの投与に より，カルシウム代謝も改善されつつある．それにか かわらず，長期透析により骨の痛みを訴える症例は多 く, RODの病態の複雑さを示している.

\section{まと め}

1. 2 施設で 10 年以上，血液透析を受けている患 者 15 人の骨変化を臨床的, X線学的に比較検討した.

2. MD 法による骨塩定量では 2 施設の患者とも全 例低下していたが, 臨床症状やX線学的変化の強い症 例はA施設に集中していた。

3. 2 施設間では水処理の方法が最も異なりはAで は軟水化装置を, Bでは逆浸透装置を用いてあり, 透 析水に対する十分な配慮が必要であると思われた。

\section{参 考 文 献}

1) 伊東昌子：CT による透析患者の椎体海綿骨・皮質 骨の骨塩量の検討. 日本放射線学会雑誌, 49： 1382-1389, 1989. 
2）丸茂文昭, 栗山廉二郎：腎疾患・透析と微量元素, 最新医学, $45: 701-705,1990$.

3）鈴木正司：腎性骨異栄養症におけるアルミニウムの 役割。第 2 回腎と骨代謝研究会記録，59-79,1984。
4）楊鴻生，富永浩司：血液透析患者の骨粗鬆化につい てーMD 法の各パラメーターを中心に一。整形災害外 科, $31: 361-368,1989$. 